\title{
Free Complement C5 Measurement
}

National Cancer Institute

\section{Source}

National Cancer Institute. Free Complement C5 Measurement. NCI Thesaurus. Code C161357.

The determination of the amount of free complement C5 present in a sample. 